\title{
Spatial and temporal trends of polycyclic aromatic hydrocarbons in wild mussels from the Cantabrian coast (N Spain) after the Prestige oil spill $\dagger$
}

\author{
José Antonio Soriano, ${ }^{a}$ Lucía Viñas, ${ }^{* a}$ María Angeles Franco, ${ }^{a}$ \\ Juan José González, ${ }^{a}$ Manh Hieu Nguyen, ${ }^{b}$ Josep María Bayona $^{b}$ and \\ Joan Albaigés ${ }^{b}$
}

Received 2nd April 2007, Accepted 12th June 2007

First published as an Advance Article on the web 27th June 2007

DOI: $10.1039 / b 704989 g$

Polycyclic aromatic hydrocarbon (PAH) levels were determined in tissues of wild mussels (Mytilus galloprovincialis) collected at 17 stations along the Cantabrian coast (N Spain), from Navia (Asturias) to Fuenterrabía (Basque Country), in order to assess the extent of the environmental impact caused by the Prestige oil spill (November 13, 2002).

Six sampling campaigns were carried out in April, June and November in 2003 and 2004.

The comparison of PAH data with those obtained earlier in 2000 showed a widespread pyrolytic and petrogenic contamination and allowed an estimation, for the first time, of the background pollution in the region and identification of the chronic hotspots. The spatial distribution found in the first samples after the oil spill revealed the eastern area as the most affected due to the continuous arrival of fuel slicks since early summer 2003. Several stations in this area showed increased total PAH concentrations of up to 15 times the pre-spill levels, which did not recover until April 2004, more than one year after the accident. Molecular parameters within the aliphatic and aromatic fractions were determined to assess the presence of Prestige oil in these samples.

\section{Introduction}

The Prestige oil spill occurred in November 2002 in front of the Galician coast (NW Spain), on the grounding of an oil tanker transporting about 77000 tonnes of heavy fuel-oil, and produced one of the largest ecological disasters in Spanish history. Oil discharged from the Prestige during its towing away from the coast and after its sinking $240 \mathrm{~km}$ off the NW coast of Spain, reached the adjacent Galician coast rapidly; but oil drifting $\mathrm{NE}$ arrived in Asturias by early December, and in Cantabria and the Basque Country in early summer, thereby affecting the entire Northern coast of Spain. ${ }^{1}$

Soon after the accident, a monitoring program was established by the Instituto Español de Oceanografía (IEO) in order to assess the spatial distribution and temporal evolution of petrogenic hydrocarbons in the affected area, which involved the sampling of water, sediments and indigenous populations of mussels. Although the strongest impact was recognised in Costa da Morte (Galicia), ${ }^{2-4}$ the survey was extended to the whole Northern coast where, in Cantabria, a daily average of 40 tons of oiled waste was still

\footnotetext{
${ }^{a}$ Instituto Español de Oceanografia, Centro Oceanográfico de Vigo, Cabo Estai-Canido, 36200 Vigo, Spain.E-mail: lucia.vinas@ieo.es; Fax: + 34986498626

${ }^{b}$ Department of Environmental Chemistry, CID-CSIC, Jordi Girona Salgado, 18-26, 08034 Barcelona, Spain

$\dagger$ Electronic supplementary information (ESI) available: Concentrations of PAHs in wild mussels on indicated dates and coordinates of the sampling sites. See DOI: $10.1039 / \mathrm{b} 704989 \mathrm{~g}$
}

being collected during summer 2003, with maximum values of over 100 tons.

Wild mussels (Mytilus galloprovincialis) have been extensively used as sentinel organisms for monitoring the uptake and accumulation of hydrophobic contaminants in coastal environments, including polycyclic aromatic hydrocarbons (PAHs) ${ }^{5,6}$ In this respect, they have been used successfully to evaluate the impact of oil spills such as the Exxon Valdez in Alaska, ${ }^{7}$ the Aegean Sea in NW Spain, ${ }^{8}$ the Braer in the Shetland Islands, UK, ${ }^{9}$ the Sea Empress in Wales ${ }^{10}$ and the Erika on the French coast. ${ }^{11}$

Besides the efficient use of these monitors, the assessment of oil pollution requires the development of analytical techniques that are able to differentiate oil residues from other sources. Characteristic molecular patterns within the aliphatic and aromatic hydrocarbon fractions have been used for this purpose. These include steranes and triterpanes as well as the relative distributions of alkylated polycyclic aromatic hydrocarbons. ${ }^{4,8,12}$

In order to assess the extent of the impact caused by the Prestige oil spill on the Cantabrian coastal ecosystem (N Spain), six sampling campaigns were carried out in April, June and November in 2003 and 2004 to collect mussels at 17 stations along the coast, from Navia (Asturias) to Fuenterrabía (País Vasco) (Fig. 1). These stations have been monitored regularly for parent PAHs by HPLC, within the IEO monitoring programme, and the existence of previous data was important for comparing contamination levels before and after the spill, identifying the hotspots and for agreement on baseline reference values. The samples were also analysed for 


\section{$\square 2000$ OCT $\square 2003$ APR $=2003$ JUN 12003 NOV $\nabla 2004$ NOV}
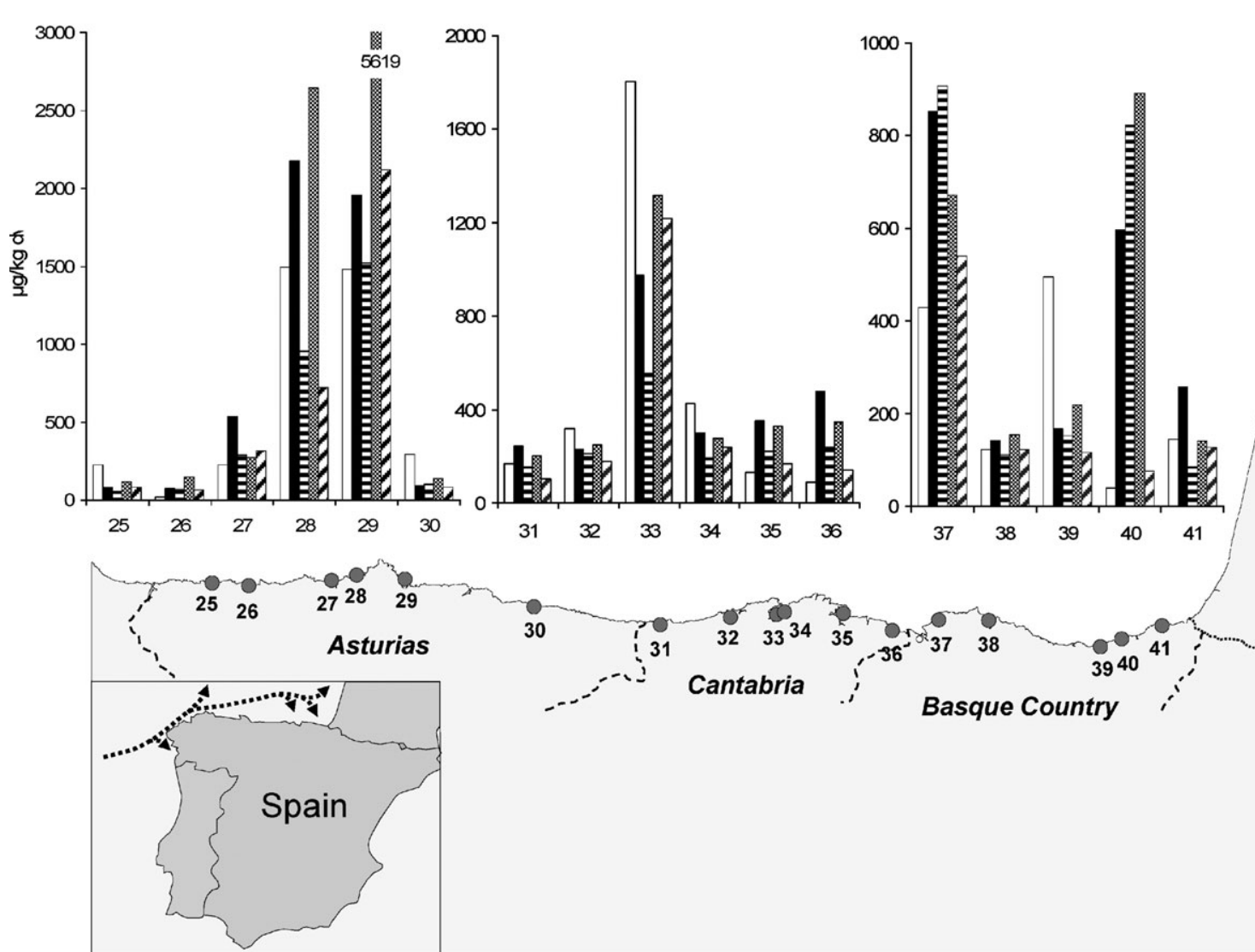

Basque Country

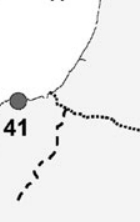

Fig. 1 Location of mussel sampling sites along the Spanish Northern coast, and PAH concentrations ( $\mu \mathrm{g} \mathrm{kg}^{-1} \mathrm{dw}$ ) in October 2000; April, June and November 2003 and November 2004.

aliphatic and aromatic hydrocarbons by GC-MS to identify the sources by molecular fingerprinting.

\section{Materials and methods}

\section{Sample handling}

Wild mussels were collected manually and stored at $-20{ }^{\circ} \mathrm{C}$ until analysis. About 50 specimens were pooled as a composite sample representative of each location and sampling period. Once the samples were thawed, mussels were homogenised and freeze-dried.

\section{Chemical analyses}

Reagents. A standard solution containing the 16 Environmental Protection Agency (EPA) PAHs (10 ng $\mu \mathrm{l}^{-1}$ in cyclohexane) was purchased from Dr Ehrenstorfer (Augsburg, Germany). Perdeuterated standards (naphthalene- $d_{8}$, anthracene- $d_{10}$, pyrene- $d_{10}$ and benzo[ $\left.a\right]$ pyrene- $d_{12}$ ), used as surrogates, were obtained from Cambridge Isotope Laboratories (Andover, USA). Suprasolv grade methanol, hexane and dichloromethane (GR for analysis) were obtained from Merck (Darmstadt, Germany). Silica gel (0.063-0.2 mm) and alumina 90 active neutral for column chromatography were also obtained from Merck.
Analytical procedure. About 2-4 g of dried mussel tissues from each station and sampling period were Soxhlet extracted with a $1: 3$ acetone-hexane mixture or dichloromethane for $12 \mathrm{~h}$ and analysed as described elsewhere. ${ }^{4}$ HPLC was used for a primary survey of parent PAHs, according to the current monitoring programme in the region, and GC-MS for full characterisation of the aliphatic and aromatic fractions. In summary, samples to be analysed by HPLC were submitted to a clean-up step by column chromatography on deactivated alumina (10\% water) with hexane elution. The 13 PAHs (phenanthrene, anthracene, fluoranthene, pyrene, chrysene, benz $[a]$ anthracene, benzo[ $b]$ fluoranthene, benzo $[k]$ fluoranthene, benzo[a]pyrene, benzo[e]pyrene, indeno[1,2,3-cd]pyrene, dibenz $[a, h]$ anthracene and benzo[ghi]perylene) were determined by HPLC (HP 1100 apparatus, Agilent Technologies, Palo Alto, CA, USA) coupled with a wavelength programmable fluorescence detector (HP 1036, Agilent Technologies, Palo Alto, CA, USA), using a Vydac 201 TP column (Grace Vydac, Hesperia, CA, USA), eluting with a methanol-water gradient.

Certified solutions, supplied by Dr Ehrenstorfer, were used in the quantification. The analytical method was subject to a continuous external quality control process by participation in the Quality Assurance of Information for Marine Environmental Monitoring in Europe exercises. ${ }^{13}$ The limit of 
detection (LOD) was in the range of 0.1 to $0.4 \mu \mathrm{g} \mathrm{kg}{ }^{-1} \mathrm{dw}$ for phenanthrene to indeno[1,2,3-cd]pyrene.

The extracts to be analysed by GC-MS were fractionated by column chromatography with $6 \mathrm{~g}$ of neutral alumina (top) and $6 \mathrm{~g}$ of silica gel (bottom), both $5 \%$ deactivated with MilliQ water. Two fractions were collected; the first one, containing the aliphatic hydrocarbons, eluted with $20 \mathrm{ml}$ of hexane, and the second, containing the PAHs, eluted with $50 \mathrm{ml}$ of hexane-dichloromethane $(80: 20)$. The second fraction was solvent exchanged to dichloromethane $(1 \mathrm{ml})$ and cleaned by gel permeation chromatography using a BioBeads S-X12 column $(45 \times 1.0 \mathrm{~cm})($ Teknokroma, Sant Cugat, Spain) and dichloromethane as the mobile phase. The isolated fractions were analysed by gas chromatography coupled to mass spectrometry using a Trace Thermo-Electron Corporation (Austin, TX, USA) apparatus in the electron impact mode at $70 \mathrm{eV}$. A $30 \mathrm{~m} \times 0.25 \mathrm{~mm}$ ID capillary column coated with $0.25 \mu \mathrm{m}$ of DB-5MS stationary phase (J\&W Scientific, Folsom, CA, USA) was temperature programmed as follows: at $60{ }^{\circ} \mathrm{C}$ for $1 \mathrm{~min}$, until $200{ }^{\circ} \mathrm{C}$ at $10{ }^{\circ} \mathrm{C} \mathrm{min}{ }^{-1}$ and finally to $320{ }^{\circ} \mathrm{C}$ at $4.8^{\circ} \mathrm{C} \mathrm{min}{ }^{-1}$, holding that temperature for $10 \mathrm{~min}$. Acquisition was performed in the full scan mode from 50 to $350 \mathrm{amu}$ at 2 scans s${ }^{-1}$ and starting after $6 \mathrm{~min}$. The LOD in the full scan mode ranged from 0.7 to $3.4 \mu \mathrm{g} \mathrm{kg}^{-1} \mathrm{dw}$ for phenanthrene and benzo $[a]$ pyrene, respectively.

\section{Results and discussion}

\section{PAH concentrations in wild mussels}

The total concentrations of the 13 parent PAHs determined in the collected samples in October 2000 and through 2003 and 2004, after the Prestige oil spill, are shown in Fig. $1 \uparrow$. In April 2003 , five months after the spill, the higher concentrations were found at stations 28 and 29 , with values around $2000 \mu \mathrm{g}$ $\mathrm{kg}^{-1} \mathrm{dw}$, although they were attributed to the vicinity of urban and industrial areas because the levels were similar to those found before the spill and continued to be higher during the whole sampling period. Another station, located close to the oil terminal of Santander (station 33), exhibited a similar trend, but with concentrations around $1000 \mu \mathrm{g} \mathrm{kg}^{-1} \mathrm{dw}$. These could be considered as the main "hotspots" of the region.

The lower concentrations, below $100 \mu \mathrm{g} \mathrm{kg}^{-1} \mathrm{dw}$, were found at stations 25, 26 and 30, on the Asturian coast. Values in the lower range were also found at two stations in the Basque Country (nos. 38 and 39), located in the inner part of the estuaries (rias).

At the rest of the stations, concentrations ranged from 228 to $851 \mu \mathrm{g} \mathrm{kg}^{-1} \mathrm{dw}$, suggesting different degrees of contamination. Some of them, e.g. Laredo (st. 35), Castro-Urdiales (st. 36), Bilbao-Azcorri (st. 37), Igueldo (st. 40) and Fuenterrabia (st. 41), exhibited a significant increase (up to 15 times) with respect to the corresponding pre-spill values (Fig. 1). This could be the result of the impact of the spill, although the levels found did not reach those observed in the area of Costa da Morte (Galician coast) in February 2003, which was the most severely impacted area. ${ }^{4}$

The location of these stations, at the eastern part of the Cantabrian coast, is consistent with the trajectory of the oil in the region that, driven by the winds and the surficial currents, crossed the NW coast of Spain outside the continental shelf and, passing by the edge of the Asturian coast, travelled to the Gulf of Biscay ${ }^{14}$ (Fig. 1). The studies carried out on the occurrence of oil residues at the bottom of the continental shelf, in March 2003, also revealed a greater presence of tar aggregates at the eastern part of the Cantabrian coast. ${ }^{15}$

In the following sampling campaign (June 2003), a general decrease of the total PAH concentrations occurred in the majority of the affected stations, possibly reflecting a depletion of the Prestige oil pollution but also the biological seasonal variability. The decrease of PAH concentrations in late spring/ early summer, matching the mussel spawning period, has been described in other studies. ${ }^{4,16}$ Conceivably, the further increase observed in November could also be attributed to seasonal variations of PAH concentrations in response to lower metabolising capacities because of lower temperatures, and higher lipid contents in mussel tissues in autumn/winter, before the spawning period. ${ }^{17}$ Nevertheless, in stations 37 (BilbaoAzcorri) and 40 (Igueldo), the concentrations were still increasing, consistent with the oil trajectories and the late arrival of the fuel-oil to this area. In fact, the beach of Azcorri was one of the most affected by successive arrivals of fuel oil in the Basque Country.

The concentrations of PAHs did not recover the values found before the Prestige spill (October 2000) until April 2004, more than one year after the accident. In summary, the first data on concentrations of PAHs in mussels collected along the Cantabrian coast show that concentrations below $50 \mu \mathrm{g} \mathrm{kg}^{-1}$ $\mathrm{dw}$ could be considered as the background pollution in the region and values above $200 \mu \mathrm{g} \mathrm{kg}^{-1} \mathrm{dw}$ reflected the vicinity of certain urban or industrial hydrocarbon sources. In several stations the sum of 13 PAHs was above $1000 \mu \mathrm{g} \mathrm{kg}^{-1} \mathrm{dw}$, corresponding to chronic pollution by urban/industrial runoff, and clearly assigned them as hotspots. These reference levels are slightly over those previously found on the Galician coast ${ }^{4}$ and are similar to those observed in other Spanish coastal $\operatorname{areas}^{18}$ and in France before the Erika oil spill. ${ }^{19}$

\section{PAH distribution patterns}

The relative abundances of the parent and alkylated PAHs may provide useful signatures for recognising hydrocarbon sources in the environment and the impact of oil spills. ${ }^{12,20}$ Representative distributions of parent PAHs are shown in Fig. 2. The mussels collected before the spill in October 2000 at the urban/industrial sites of Avilés, Gijón and Santander, showed the whole set of 3- to 6-ring PAHs, with a relative predominance of pericondensed derivatives (e.g. fluoranthene and benzofluoranthenes), currently considered as combustion-derived. However, the concurrence of alkylated components (not shown) was consistent with a mixed petrogenic-pyrolytic input. This type of profile has been widely reported in chronically polluted coastal areas. ${ }^{6,8,21}$ The distributions found in more pristine stations (e.g. Navia and Luarca) were similar, reflecting the background contamination of the region. In fact, the average PAH composition for all stations in October 2000 (Fig. 3) illustrates the widespread occurrence of these hydrocarbons despite the levels found in each station. 

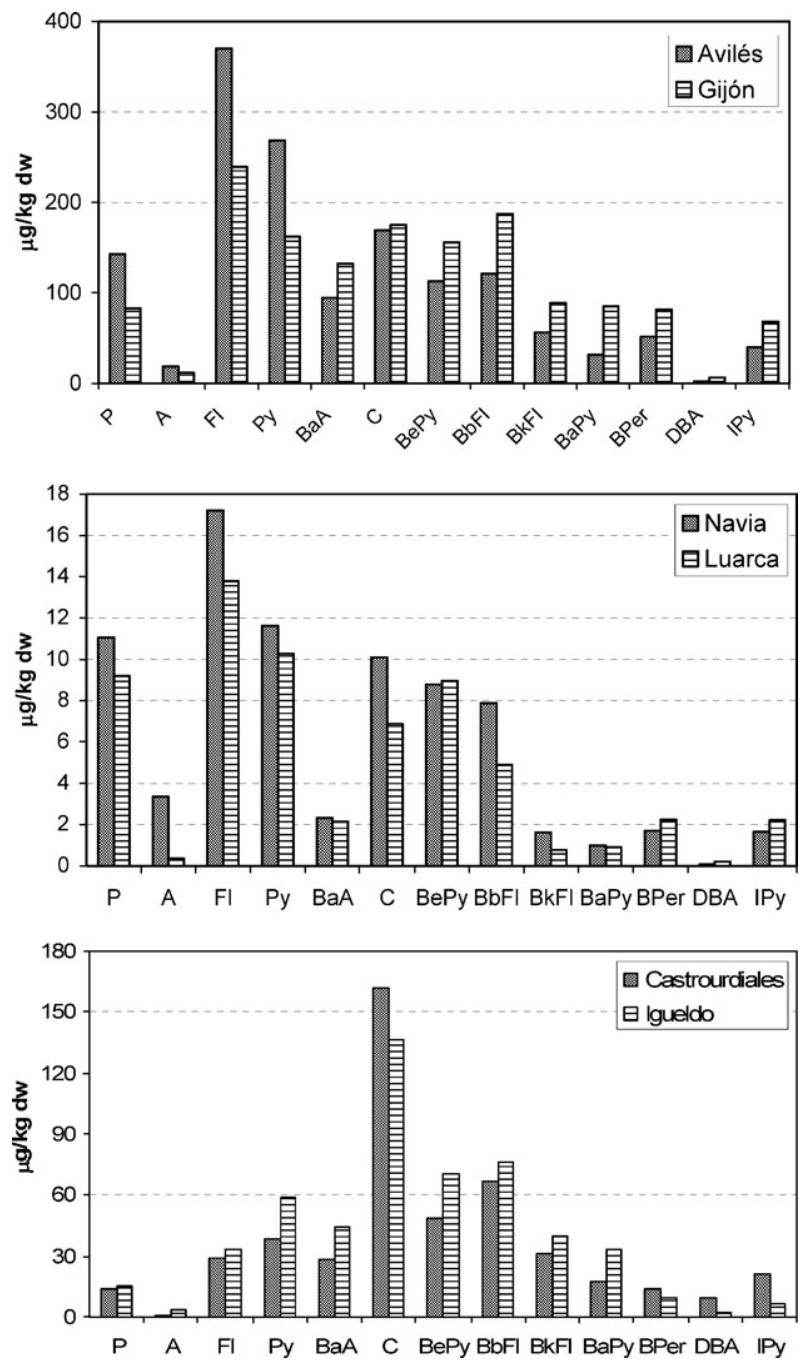

Fig. 2 Representative PAH distributions in mussels collected in October 2000 in Avilés, Gijón (top), and in April 2003 Navia, Luarca (centre), and Castro-Urdiales, Igueldo (bottom). P: phenanthrene; A: anthracene; Fl: fluoranthene; Py: pyrene; BaA: benz $[a]$ anthracene; $\mathrm{C}$ : chrysene; BePy: benzo[e]pyrene; $\mathrm{BbFl}$ : benzo[b]fluoranthene; $\mathrm{BkFl}$ : benzo $[k]$ fluoranthene; BaPy: benzo[ $a]$ pyrene; BPer: benzo[ghi]perylene; DBA: dibenz[$[a, h]$ anthracene; IPy: indeno[1,2,3-cd]pyrene.

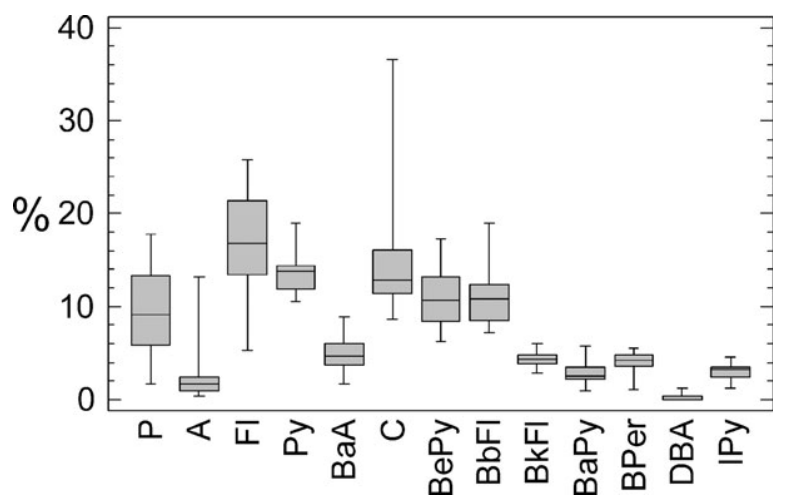

Fig. 3 Average PAHs composition (box- and whisker plots) for all stations in October 2000.
Conversely, in April and June 2003, the PAH distributions in mussels from a number of stations (e.g. Laredo, CastroUrdiales and Igueldo) were clearly dominated by chrysene. This was also found in stations affected by the Aegean Sea, Erika and Nakhodka oil spills, ${ }^{8,11,22}$ as well as on the Galicia coast after the Prestige spill, ${ }^{4}$ thus serving as an indication of recent oil inputs. Consistently, concentrations increased significantly in those stations after the spill and therefore were considered as affected. The higher abundance of alkyl-substituted over unsubstituted PAHs was also consistent with the predominance of the petrogenic components.

A radial presentation of the percentages of each PAH in different stations along the survey period may contribute to illustrate the temporal impact of the spill. Representative stations are shown in Fig. 4. The profiles of Pravia and Santander-Pedreña stations (27 and 34), that were not reached by the oil, show a conservative profile, characteristic of the background/chronic contamination. This type of mixed profile is common in coastal sediments of urban/industrial areas ${ }^{23,24}$ and is currently attributed to chronic runoff inputs. On the other hand, the stations affected by the spill displayed a totally different profile. A representative example corresponds to the Laredo and Castro-Urdiales stations (35 and 36) where, from April to November 2003, the profile exhibited a predominance of chrysene, and did not recover the profile formerly found in the 2000 survey until April 2004, due to the long lasting effect of the spill in this region.

\section{Oil source recognition}

Different ratios of individual components were defined for assessing the origin and extent of the oil spill in mussels from the Galicia coast, such as the fluoranthene/pyrene and chrysene/benzofluoranthenes ratios. ${ }^{4}$ However, the values found in the Cantabrian coast mussels were more difficult to correlate with the oil. Only stations 35 (Laredo), 36 (Castro-Urdiales) and 40 (Igueldo), at the eastern edge of the coast, exhibited values nearer to those of the Prestige fuel oil ( 0.28 and 2.40, respectively) during April-November 2003. Similarly, the methylphenanthrene/methyldibenzothiophene ratios, also found to be of diagnostic value, exhibited values during 2003 in the range of 3.1 to 18.5 , in all stations except $35-37$ and 40 , for which they were below 1.0, much closer to the Prestige fuel oil value $(0.3)$.

Molecular fingerprinting of the aliphatic fraction has also been widely used for source recognition of oil spill residues but more rarely in biota. ${ }^{20,25,26}$ In order to confirm the above relationship of the petrogenic hydrocarbons with the suspected source, namely the Prestige fuel oil, the hopane and sterane profiles were determined in the aliphatic fractions of the mussel extracts. The presence of these molecular markers in all samples indicates the widespread occurrence of petrogenic contamination. The diagnostic molecular parameters of the fuel oil and those of representative mussel samples are shown in Fig. 5. In general, the values displayed by the samples are clearly different from those of the Prestige oil and can be considered as representative of the regional background pollution, as previously observed in areas of the Galicia coast not affected by oil spills. ${ }^{4,8}$ However, the profiles displayed by 


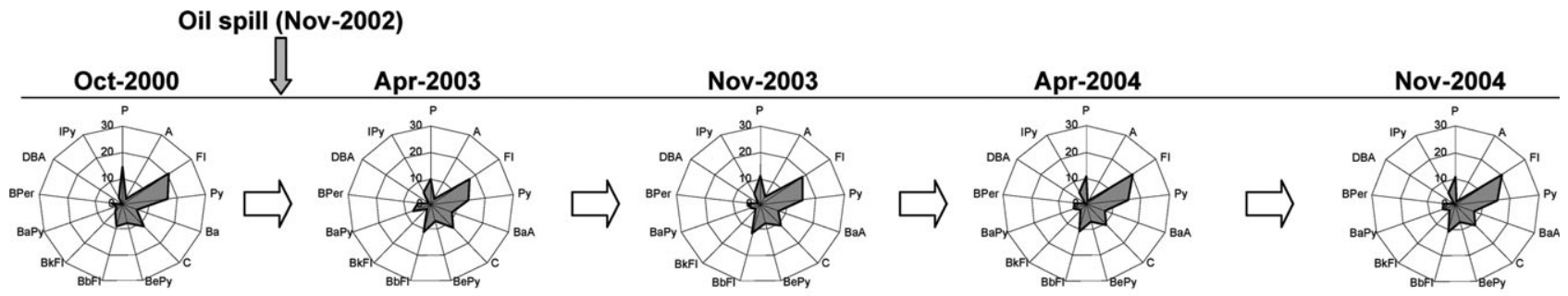

St. 27- Pravia
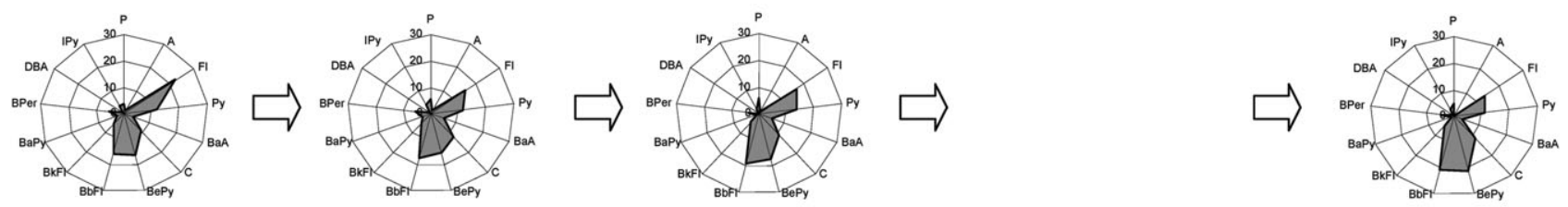

\section{St. 34 - Santander-Pedreña}
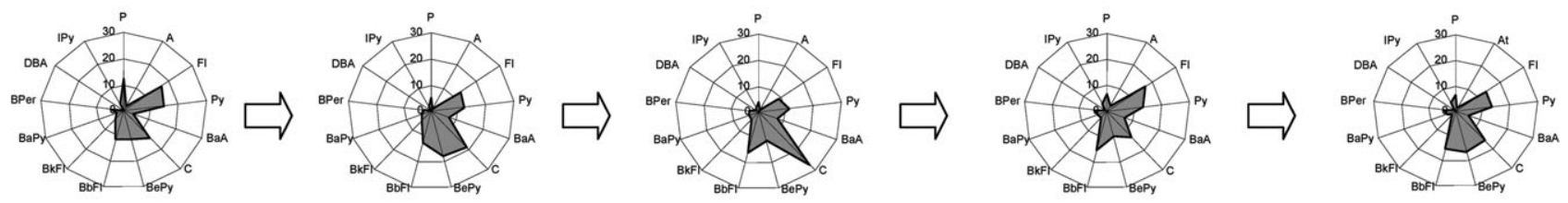

\section{St. 35 - Laredo}
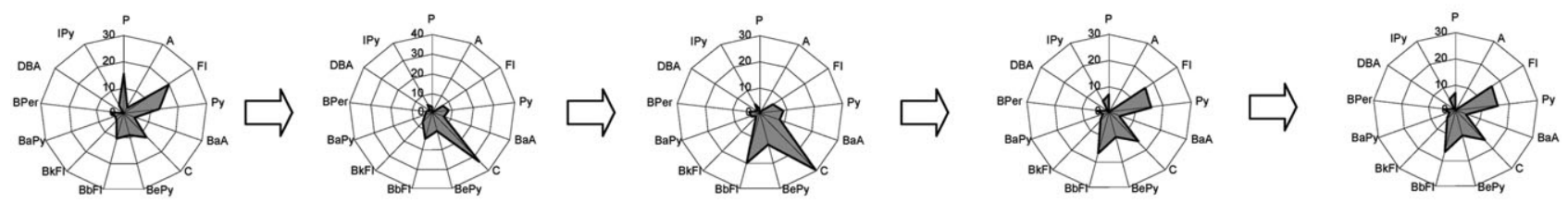

Fig. 4 Radial representation of the PAH distributions in mussels from stations 27, 34, 35 and 36 in October 2000, April and November 2003 and April and November 2004.

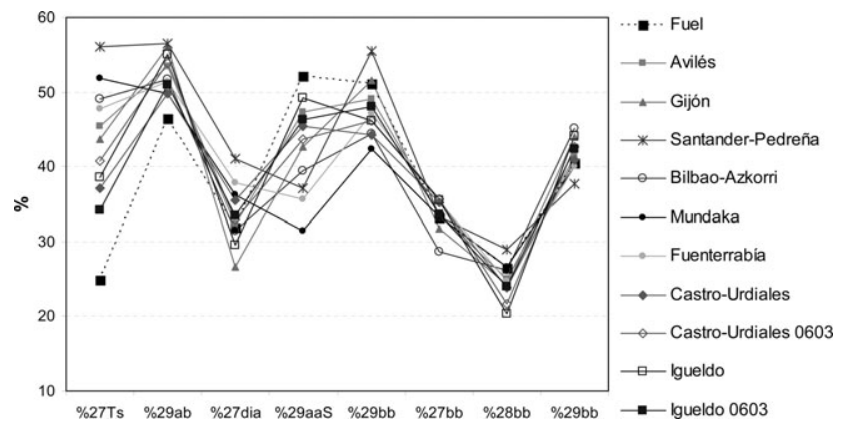

Fig. 5 Sterane and triterpane source diagnostic ratios of hydrocarbons from mussel tissues of samples collected in April and June 2003, compared with those of the original fuel. Index definitions as in Soriano et al. ${ }^{4}$

some samples (e.g. Castro-Urdiales and Igueldo) were in an intermediate position, suggesting a possible mixture of the Prestige oil with the pre-existing (chronic) pollution.

The failure to detect the presence of the spilled oil above the background pollution using molecular parameters within the aliphatic and aromatic fractions was also observed in subtidal sediments and was attributed to the heavy nature of the oil. This was barely dispersed in the water column and mainly stranded on the coast or sedimented in the form of oil patches ${ }^{3}$ and only moderately taken up by mussels and recognised in their tissues by specific compositional trends.

In conclusion, these results indicate that the impact of the Prestige spill on wild mussels was lower in Cantabria than in Galicia, and that PAH concentrations returned to pre-spill levels in most areas one year after the accident. However, besides the oil spill that can be of an occasional concern, in some areas (hotspots) marine biota can be chronically exposed to background pollution, so that long-term exposure to PAHs from other sources may be a potential threat.

\section{Acknowledgements}

This work was supported by the Spanish Ministry of Science and Technology (VEM2003-20068-C05). The authors would like to thank the lab staff for the technical support in the collection and preparation of the samples.

\section{References}

1 J. Albaigés, B. Morales-Nin and F. Vilas, Mar. Pollut. Bull., 2006, 53, 205-207.

2 J. J. González, L. Viñas, M. A. Franco, J. Fumega, J. A. Soriano, G. Grueiro, S. Muniategui, P. López Mahía, D. Prada, 
J. M. Bayona, R. Alzaga and J. Albaigés, Mar. Pollut. Bull., 2006, 53, 250-259.

3 M. A. Franco, L. Viñas, J. A. Soriano, D. De Armas, J. J. Gonzalez, R. Beiras, N. Salas, J. M. Bayona and J. Albaigés, Mar. Pollut. Bull., 2006, 53, 260-271.

4 J. A. Soriano, L. Viñas, M. A. Franco, J. J. González, L. Ortiz, J. M. Bayona and J. Albaigés, Sci. Total Environ., 2006, 370, 180-90.

5 T. O'Connor, Mussel Watch results from 1986 to 1996, Mar. Pollut. Bull., 1998, 37, 14-19.

6 P. Baumard, H. Budzinski, Q. Michon, P. Garrigues, T. Burgeot and J. Bellocq, Estuarine, Coastal Shelf Sci., 1998, 47, 77-90.

7 D. S. Page, P. D. Boehm, J. S. Brown, J. M. Neff, W. A. Burns and A. E. Bence, Mar. Environ. Res., 2005, 60, 422-436.

8 C. Porte, X. Biosca, D. Pastor, M. Sole and J. Albaigés, Environ. Sci. Technol., 2000, 34, 5067-5075.

9 L. Webster, L. Angus, G. Topping, E. J. Dalgarno and C. F. Moffat, Analyst, 1997, 122, 1491-1495.

10 R. J. Law, C. A. Kelly and M. D. Nicholson, Polycyclic Aromat. Compd., 1999, 17, 229-239.

11 J. Tronczynski, C. Munschy, K. Héas-Moisan, N. Guiot, I. Truquet, N. Olivier, S. Men and A. Furaut, Aquat. Living Resour., 2004, 17, 243-259.

12 A. E. Bence and W. A. Burns, in Exxon Valdez oil spill: fate and effects in Alaskan waters, ed. P. G. Wells, J. N. Butler and J. S. Hughes, ASTM, Philadelphia, USA, 1995, p. ASTM STP 1219.

13 QUASIMEME laboratory performance studies, Round 34, BT-4 Exercise 588: Polyaromatic hydrocarbons in biota, 2003, QUASIMEME II.
14 J. M. Ruiz-Villarreal, C. González-Pola, G. Díaz del Río, A. Lavín, P. Otero, S. Piedracoba and J. M. Cabanas, Mar. Pollut. Bull., 2006, 53, 220-238.

15 F. Sanchez, F. Velasco, J. E. Cartes, I. Olaso, I. Preciado, E. Fanelli, A. Serrano and J. L. Gutiérrez-Zabala, Mar. Pollut. Bull., 2006, 53, 332-349.

16 R. J. Law and C. Kelly, Aquat. Living Resour., 2004, 17, 389-394.

17 E. A. Dyrinda, R. J. Law, P. E. J. Dyrinda, C. A. Kelly, R. K. Pipe and N. A. Ratcliffe, Mar. Ecol.: Prog. Ser., 2000, 206, 155-170.

18 P. Baumard, H. Budzinski, P. Garrigues, J. F. Narbonne, T. Burgeot, X. Michel and J. Bellocq, Mar. Environ. Res., 1999, 47, 415-439.

19 G. Bocquené, S. Chantereau, C. Clérendeau, E. Beausir, D. Ménard, B. Raffin, C. Minier, T. Burgeot, A. P. Leszkowitz and J. F. Narbonne, Aquat. Living Resour., 2004, 17, 309-316.

20 P. D. Boehm, G. S. Douglas, W. A. Burns, P. J. Mankiewicz, D. S. Page and A. E. Bence, Mar. Pollut. Bull., 1997, 34, 599-613.

21 J. Hellou, S. Steller, V. Zitko, J. Leonard, T. King, T. G. Milligan and P. Yeats, Mar. Environ. Res., 2002, 53, 357-379.

22 J. Koyama, S. Uno and K. Kohno, Mar. Pollut. Bull., 2004, 49, 1054-1061.

23 D. Broman, A. Colsmjo, B. Ganning, C. Naf and Y. Zebühr, Environ. Sci. Technol., 1988, 22, 1219-1228.

24 I. Tolosa, J. M. Bayona and J. Albaigés, Environ. Sci. Technol., 1996, 30, 2495-2503.

25 P. J. C. Tibbetts, S. J. Rowland, L. L. Tovey and R. Large, Toxicol. Environ. Chem., 1982, 5, 177-193.

26 C. Porte, D. Barceló, T. M. Tavares, V. C. Rocha and J. Albaigés, Arch. Environ. Contam. Toxicol., 1990, 19, 263-274. 